\title{
Especial sobre investigación sonora
}

\section{Gustavo Celedón y Carolina Benavente, U. de Valparaíso}

El presente número de Panambí. Revista de Investigaciones Artísticas está dedicado a la investigación sonora. Su eje central lo constituye el dossier "Música, sociedad y procesos de subjetivación", a cargo de la destacada profesora Dra. Carmen Pardo, de la Universidad de Gerona, quien ha realizado una vasta e importante reflexión sobre las cuestiones sonoras.

Junto a este dossier, la sección Galería cuenta con el aporte de tres importantes artistas sonoros, Fernando Godoy y Rodrigo Ríos Zunino, en Portada, con Revolt. Instalación sonora/cinética, y Ana María Estrada, en Residencia, con La memoria chilena está en el mar. Además, se incluye una reseña escrita por Jaime Villanueva al número 3 de Aura. Revista de arte sonoro y cultural, de Tsonami Arte Sonoro.

Destacamos la importancia de la presente edición de Panambí, que nos invita a explorar las culturas, las visiones políticas, ecológicas, sociales, económicas, etc. asociadas al sonido, materia o elemento que pasa comúnmente desapercibido, no sólo en el cotidiano general, sino también en el espacio académico, estético y científico.

Es muy interesante comprobar, en este número, cómo una reflexión sobre el sonido es también una reflexión sobre los problemas actuales. Cada uno de los escritores que se dan cita en las páginas que siguen, así como también los artistas colaboradores, sorprenden por una alta preocupación por el momento presente, con todos los problemas que lo constituyen. El sonido no es una excusa, sino, más bien, todo lo contrario, una suerte de agente contemporáneo ligado a todo lo que sucede y nos sucede.

Invitamos a los lectores a sumergirse atenta y conscientemente en las páginas de este especial de Panambí dedicado a la investigación sonora. 